March, 1973, pp. 357-366.

\title{
HISTORICAL SKETCH OF THE JAPAN PHYSICAL EDUCATION ASSOCIATION IN THE LATE MEIJI ERA
}

\author{
Hideaki KINOSHITA \\ Nihon University \\ 明治時代後半における日本体育会の事業

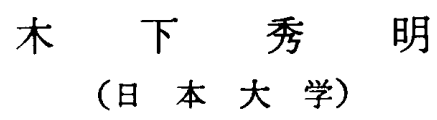

明治 24 年に設立された日本体育会は, 大正 3 年の経済的危機にいたるまで, 唯一の民間体有団体として, 社会 体育と学校体操指導者羡成に多大の貢献をしている. その創立期から最盛期を経て衰退期にむかう間の本会の活 動てついての概観である.

1. 退役下士官日高藤吉郎に上る日本体育会の創立とその概要

2. 創立期の活動である体育場, 運動会, 体操練習所, 体育講演会, 体育雅誌の刊行てついての概説

3. 閑院宮を総裁とし社団法人となって，各地飞支会を置いた日本体育会の発展状況

4. 最盛期の活動である体操学校, 夏期講習会, 模範体操場とそのクラブ, 運動場開放, 内国勧業博覧会参 加，兵事講習会など中央での概況と地方支会の活動状況の数量的一覧

5. 日本体育会の国際的地位の例示

6. 日本体育会の衰退の概観

\section{Introduction}

The Japan Physical Education Association was established in Tokyo in 1891 (the 24th year of Meiji) as a private physical education organization. It is distinguished in the Japanese history of physical education in that this association developed rapidly and became the only nationwide organization in the Meiji era (1868-1912). But this organization was forced to reduce its activities to the maintenance of schools due to the financial crisis in 1914 (the third year of Taishō). And at present, the association belongs to a school juridical body operating Nihon College of Health and Physical Education (日本体育大学), four high schools and one kindergarten.

The aim of this paper is to make a historical sketch of activities of the Association in the latter half of the Meiji era.

This historical sketch is presented by the author having been the chief editor on a book on the history of the Association and the College operated by the association, so the paper is based upon the authentic history of the subject, which will be published in the near future. 
Reference materials are the followings:

1) Documents preserved by the association.

2) Each issue of 'Bunbu Sōshi' (文武叢誌 1893-1899) and 'Taiiku' (体育 1899-1914) published by the association.

3) Chronological History of the Association (author unknown).

4) 'Essays on Physical Education by Famous Japanese and Foreigners' (内外名家体育論) edited and published by the Association in 1902.

5) 'Physical Education in Japan' (日本之体育) edited and issued by the Association in 1903.

\section{Establishment of the Japan Physical Education Association}

The Japan Physical Education Association was established in 1891 by Tokichiro Hidaka (1856-1932). He was a retired non-commissioned military officer after graduating from a non-commissioned officer's Training Camp (教導団), but he did not come from the warrior class.

After retiring from the army, he established a middle school called 'Seijō School' (成城 学校) in 1885. The aim of this school was to educate boys who aspired to be cadets. In 1891, he established the Japan Physical Education Association. The aim of this association was to encourage physical activities both on an individual basis and militaristic nationalism. The latter however was uppermost. The funds needed for the activities were the rent of buildings, membership fees, contributions, Imperial grants and so on.

\section{Early Activities}

Early activities of the Japan Physical Education Association were the following:

1) Construction of outdoor gymnasium (体育場)

2) Holding gymnastic and athletic meets (運動会)

3) Establishment of a Training Institute for Gymnastics (体操練習所)

4) Public lectures on physical education (体育講演会)

5) Publication of a periodical on physical education

\section{Construction of Outdoor Gymnasium}

Two outdoor gymnasiums were established. One was in Kanda Ward in the center of Tokyo in 1891 and the other in Hongo Ward in the northern part of Tokyo.

The aim of these outdoor gymnasiums was to offer the citizens a place for physical activities. The people who used them were divided into three classes. In A class, a person paid entrance fee every time he came. In B class, a person paid by the month and in $\mathrm{C}$ class, a person enrolled as a student and paid fixed tuition attending lessons in appointed courses leading to graduation. These courses consisted in heavy gymnastics, etc. It is presumed that the teachers were soldiers who had graduated from the Army Normal School of Gymnastics (Toyama School). The pupils consisted of boys of middle and normal schools, etc. 


\section{Gymnastic and Athletic Meets}

In November of 1891, the Japan Physical Education Association held its first gymnastic and athletic meet in the outdoor gymnasium and the second was held in the next year. The aim of this meeting, as well as that of many athletic meets of usual schools, was to encourage physical activities and to make people acquire the custom of taking exercise. The main events of such meets were heavy gymnastics which differed from the main running matches of usual school athletic meets.

\section{Establishment of a Training Institute for Gymnastics}

In Japan the National Teacher Training School of Gymnastics (体操伝習所) was established for the first time in 1878. But in 1887 the school terminated the teacher training program of gymnastics.

The Japan Physical Education Association was convinced of the necessity of the teacher training program of gymnastics and established a training institution of gymnastics at Iidamachi in the central part of Tokyo in April of 1893. The courses of this institute were divided into two courses, the regular course and elective course. There were, however, very few persons that graduated from the regular course. Many persons left school after getting their teacher's license on passing the gymnastics examination. The subjects consisted of light gymnastics, military drill, heavy gymnastics and lectures on physical education. Teachers were graduates of the Army Normal School of Gymnastics (陸軍戸山学校) and of the National Teacher Training School of Gymnastics.

The pupils of this institute aquired the middle school teacher's license in gymnatics by passing the Ministry. of Education examination with honours. In 1895 in fifteen prefectures, including Tokyo Prefecture, the graduates from this institute were issued elementary school teacher's licenses in gymnastics without this examination. This institute was renamed 'Training School of Gymnastics' (体操学校). This was the predecessor of the present Nippon College of Health and Physical Education.

\section{Public Lecture on Physical Education}

In May of 1893. the association began to hold lectures on physical education, and they were held every month after that. The aim was to make the citizens understand the meaning of physical education and encourage physical activities. In the lecture meetings in 1894 visual aids were used.

\section{Publication of a Periodical on Physical Education}

In November of 1893, the association published a monthly magazine called 'Bunbu Sōshi' (文武叢誌). This title was changed into 'Taiiku' (体有) in 1899. It contained articles on physical education, an introduction to the current events of physical education and report on the business of the society. This magazine was discontinued in 1914 after the 246th volume was published. 


\section{Development of the Japan Physical Education Association}

With the clear advancement of Japanese militarism after the Japan-China War (18941895), the association developed rapidly.

In 1898, an Imperial prince, Kan-innomiya Kotohito became the president of this association. The association was organized as corporated juridical person and branches of this organization were established all over the country. Regions and time of establishment were as follows :

$\begin{array}{lll}\text { Ōsaka Branch } & \text { Ōsaka Pref. } & \text { July, 1896 } \\ \text { Hokkaido Branch } & \text { Hokkaido } & \text { June, 1897 } \\ \text { Kanagawa Branch } & \text { Kanagawa Pref. } & \text { July, 1899 } \\ \text { Miyagi Branch } & \text { Miyagi Pref. } & \text { Nov., 1899 } \\ \text { Kagoshima Branch } & \text { Kagoshima Pref. } & \text { Nov., 1899 } \\ \text { Saitama Branch } & \text { Saitama Pref. } & \text { Jan., 1900 } \\ \text { Gunma Branch } & \text { Gunma Pref. } & \text { March, 1900 } \\ \text { Tochigi Branch } & \text { Tochigi Pref. } & \text { March, 1900 } \\ \text { Chiba Branch } & \text { Chiba Pref. } & \text { March, 1900 } \\ \text { Aichi Branch } & \text { Aichi Pref. } & \text { August, 1901 } \\ \text { Nagano Branch } & \text { Nagano Pref. } & \text { Nov., 1901 } \\ \text { Shizuoka Branch } & \text { Shizuoka Pref. } & \text { unknown }\end{array}$

The association annually accepted government grant of 10,000 yen for five years from 1899 to 1904 . The government asked this association to establish a normal school of gymnastics and to build ten standard gymnasiums all around the country. This shows that the association grew to be a nationwide organization authorized by the government.

\section{Activities at the Zenith of the Association}

Activities at the zenith of the association were broadly divided into those of Tokyo and those of the branches in the provinces.

These are the activities of Tokyo.

1. Normal School of Gymnastics (体操学校)

2. Summer School of Gymnastics（夏季体操講習会）

3. Standard Gymnasiums and Its Clubs（模範体操場）

4. Admission Free Playground

5. Participation in Domestic Industrial Exhibition

6. Course of Military Drill (兵事講習会)

\section{Normal School of Gymnastics}

The Training Institute of Gymnastics was moved to Ushigafuchi of Koji-machi ward in the central part of Tokyo in May of 1900 and at the same time was renamed 'Training School of Gymnastics'. This school was divided into two courses. One was the higher grade course the term of which was for a year and half, and the other was the regular 
course for one year. The aim of the higher grade course was to train middle school teachers of gymnastics and that of the regular course was to train elementary school teachers of gymnastics. At that time this school was the only training school for teachers of gymnastics. In June of that year, the Ministry of Education authorized middle school teacher's license in gymnastics without the examination for honour graduates from this higher grade course. In the next year to all the graduates from the course was issued the middle school teacher's license in gymnastics. In march of 1903 the authorities of all the prefectures authorized elementary school teacher's license in gymnastics without the examination for all the graduates from the regular course.

In 1903 this school established the women's regular course and for women graduates, as well as for those of men, were issued the elementary school teacher's license in gymnastics by the authorities of all the prefectures.

Motokuro Kawase (M.D.) not only studied medical science (internal medicine) but attended a school of Swedish Gymnastics in Boston, U.S.A. In 1900 when he came home, he became a teacher of this Normal School of Gymnastics and lectured on physiology, and at the same time introduced Swedish Gymnastics. He is well known for his contribution to both physiology and Swedish Gymnastics. Heizaburo, Takashima a psychologist, was the principal of this school in 1902 and he is famous for his 'Principles of Physical Education' (体育原理) published in 1904.

Both of them, with Isao Kani who became assistant professor of Tokyo Higher Normal School (東京高等師範学校) after graduating from this school, were appointed members of the Investigation Committee on Gymnastics and Games (体操遊戯取調委員会) by the Minister of Education.

Many teachers of gymnatics in the middle schools and normal schools were trained in this school during the Meiji era. At that time the only institute for training teachers of gymnastics, besides this school, was the special course of gymnastics at Tokyo Higher Normal School.

The following table shows the number of graduates of these schools classified by annual numbers.

Table 1. Annual Number of Graduates from Gymnastic Course in the Meiji Era

\begin{tabular}{c|c|c}
\hline Name of School & $\begin{array}{c}\text { Tokyo Higher } \\
\text { Normal School } \\
\text { Year of Graduate }\end{array}$ & $\begin{array}{c}\text { Normal School } \\
\text { of Gymnastics } \\
\text { (Number of graduates) }\end{array}$ \\
\hline 1881 & 21 & \\
2 & 28 & \\
3 & 22 & \\
4 & 17 & \\
5 & $6 !$ & \\
6 & 22 & \\
7 & & \\
8 & &
\end{tabular}


Table 1. (continued)

\begin{tabular}{|c|c|c|c|}
\hline Year of & $\begin{array}{l}\text { Name of School } \\
\text { Graduate }\end{array}$ & $\begin{array}{c}\text { Tokyo Higher } \\
\text { Normal School } \\
\text { (Number of graduates) }\end{array}$ & $\begin{array}{c}\text { Normal School } \\
\text { of Gymnastics } \\
\text { (Number of graduates) }\end{array}$ \\
\hline \multicolumn{4}{|c|}{1890} \\
\hline \multicolumn{4}{|c|}{1} \\
\hline \multicolumn{4}{|c|}{2} \\
\hline & 3 & & 5 \\
\hline & 4 & & 10 \\
\hline & 5 & & 12 \\
\hline & 6 & & 17 \\
\hline & 7 & & 18 \\
\hline & 8 & & 20 \\
\hline & 9 & & 22 \\
\hline & 1900 & & 17 \\
\hline & 1 & 22 & 83 \\
\hline & 2 & & 20 \\
\hline & 3 & & 105 \\
\hline & 4 & & 74 \\
\hline & 5 & 15 & 130 \\
\hline & 6 & & 186 \\
\hline & 7 & & 120 \\
\hline & 8 & & 90 \\
\hline & 9 & 35 & 103 \\
\hline & 1910 & & unknown \\
\hline & 1 & 16 & unknown \\
\hline & 2 & & 31 \\
\hline & Total & 264 & above 1,063 \\
\hline
\end{tabular}

\section{Summer School of Gymnastics}

This school held a summer school in gymnastics during summer vacation in addition to regular and higher courses. This summer school was held for teachers of elementary school with the support of Tokyo Prefecture. The aim of this schooling was to elevate the way the present teachers of gymnastics would teach physical education. The total number of participants was 850 by 1902 .

\section{Standard Gymnasium and Its Clubs}

In 1899 the association was appointed by the Minister of Education to build ten model fields of gymnastics.

In 1900 the association built a model field (inncluded training school of gymnastics) which covered an area of about 1.6 acres at Ushigafuchi in the central part of Tokyo. This field consisted of the offices, class-rooms, an indoor gymnasium and an athletic field. 
The apparatus of heavy gymnastics were two swings, one horizontal bar, one horse, one swinging beam, one table and one set of parallel bars.

This model standard gymnasium organized these clubs for the citizens who used it; heavy gymnastics, short-distance shooting, Japanese archery, Japanese fencing, horsemanship, bicycle riding and women's club of athletic and dancing.

Besides these clubs there seemed to be others as well: baseball, lawn tennis, football and cricket. In 1903 a roller skating club was added.

A swimming club was opened at the Sumida in the eastern suburbs of Tokyo in the summer of 1894 , and since then this club continued every year.

The rowing club was opened at Sumida in 1899 , and five cutters were used.

\section{Admission Free Playground}

The clubs of the standard gymnasium charged for admission. But this model standard gymnasium was opened without a fee on Sunday to encourage physical activities.

In addition to this gymnasium the association made the citizens use a few apparatuses without a fee, setting them up in a few parks in Tokyo.

Table 2. Lists of Apparatus in Each Park

\begin{tabular}{l|c|c|c|c}
\hline \multicolumn{1}{c|}{ Kind of Apparatus } & Swing & Horizontal Bar & Balancing Beam & $\begin{array}{c}\text { Circular Parallel } \\
\text { Bar }\end{array}$ \\
Name of Park & 1 & & 1 & 1 \\
\hline Ueno Park & 1 & 1 & 1 & 1 \\
Asakusa Park & 1 & 1 & & \\
Shiba Park & 1 & 1 & 1 & \\
Sakamoto Park & 1 & 1 & & \\
Fukagawa Park & & &
\end{tabular}

In June of 1903, the association sent letters to the district authorities concerned, the text of which was a request of opening the playgrounds of elementary schools for the citizens on Sunday or holidays.

And in November of that year, the Ministry of Education sent letters of the same text to the district authorities concerned.

\section{Participation in Domestic Industrial Exhibition}

In 1903 the fifth domestic industrial exhibition was opened in Osaka City. The association participated in this exhibition to encourage physical activities. In this place the association secured a field for demonstrations and erected a building to exhibit new and old sporting goods.

The next domestic industrial exhibition was opened in Ueno Park of Tokyo in 1907. The association participated also in this exhibition and built a two-storied gymnasium where 
a heated pool and a place to practise heavy gymnastics were included. This swimming pool was the first of such type in modern Japan. The association participated in the next exhibition in 1914 , too.

These participations in domestic industrial exhibitions required large funds due to the cost of erecting and taking down the building.

\section{Course of Military Drill}

One of the purposes of the Japan Physical Education Association was to encourage physical activities for the promotion of militaristic nationalism in Japan. In the view of this, in 1897 the association began to train prospective soldiers for the army in military drill, and continued to do so every year, The contents of this military drill consisted of gymnastic exercises, drills and elements of military knowledge.

The next table are facilities and equipments of provincial branches, clubs and the number of graduates from this course.

These facilities and this equipment were used by each organization of the clubs or courses.

The Osaka Branch especially was brisk in activities. The association intended to enlarge more branches all over the country, following the example of the activities of the Osaka Branch. But the association was unsuccessful in doing so.

The association also investigated eagerly into the situation of physical activities in foreign countries, because it was sure that physical education would develop better by investigating the situation in advanced countries, such as U.S.A. and countries in Europe, rather than by looking only at that of Japan.

In 1900 Masaji, Yamane voluntary manager of the association and superintendent of the sanitary section of the metropolitan police, was dispatched to Paris to attend the International Hygiene Conference. The association asked him not only to attend the International Physical Education Conference but to investigate into condition of physical activities in America and Europe. After coming home, he made a report, which was published in the magazine of the association, 'Taiiku'.

As a result of his attending this meeting, in October of 1905, he received an invitation asking the Japanese to join in the Olympic Games commemorating the 10th anniversary of their revival in 1906, but Japanese participation in these Olympic Games was not actualized.

\section{Decline of the Association}

As government grant expired in 1904, due to financial circumstances, the office of the association, the Normal School of Gymnastics and the model standard gymnasium were moved to $\bar{O}_{i}$ village in Ebara county in the western suburbs of Tokyo. Consequently participants in each club decreased, and the membership fee and contributions were reduced. At the time of this movement the association established a middle school. Since then the main undertaking of the association was to manage this middle school and the Normal School of Gymnastics. 


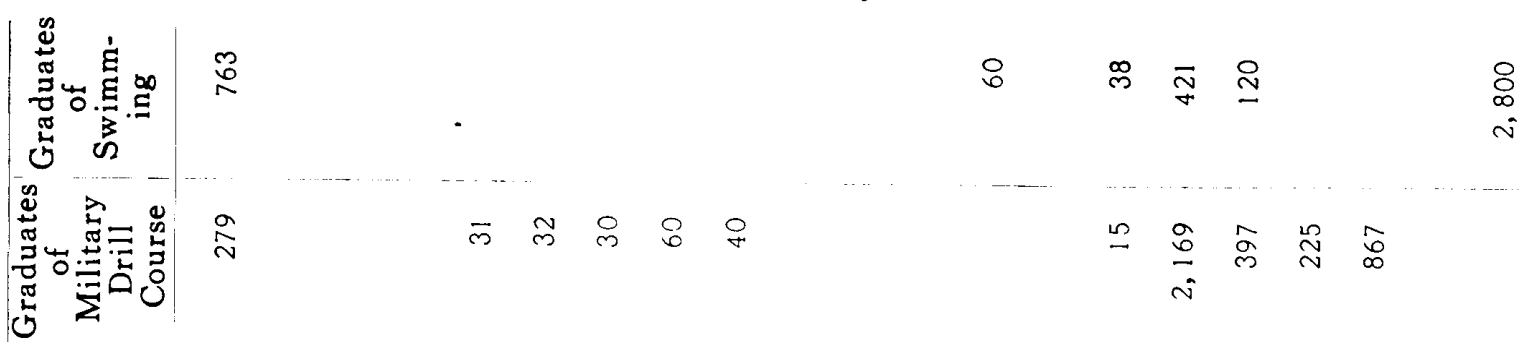


As the association participated three times in domestic industrial exhibitions, it made a great outlay for them. Participation in the exhibition in 1914 especially hit the association financially. As a result the Japan Physical Education Association could not help giving up sponsoring physical activities for the citizens. It was turned into an organization which only maintained a middle school and the Normal School of Gymnastics.

Since then the Japan Physical Education Association has not undertaken the sponsorship of physical activities for citizens but is simply a school juridical person, the main purpose of which is to train teachers of physical edncation. 